University of Nebraska - Lincoln

DigitalCommons@University of Nebraska - Lincoln

Papers in the Earth and Atmospheric Sciences

Earth and Atmospheric Sciences, Department

2009

\title{
Phytoplankton productivity across prairie saline lakes of the Great Plains (USA): a step toward deciphering patterns through lake classification models
}

\author{
Courtney R. Sahm \\ University of Wisconsin, courtney.salm@umit.maine.edu \\ Jasmine E. Saros \\ University of Maine, Orono, jasmine.saros@maine.edu \\ Sherilyn C. Fritz \\ University of Nebraska-Lincoln, sfritz2@unl.edu \\ Christopher L. Osburn \\ US Naval Research Laboratory, Washington, DC \\ David M. Reineke \\ University of Wisconsin - La Crosse
}

Follow this and additional works at: https://digitalcommons.unl.edu/geosciencefacpub

Part of the Earth Sciences Commons

Sahm, Courtney R.; Saros, Jasmine E.; Fritz, Sherilyn C.; Osburn, Christopher L.; and Reineke, David M., "Phytoplankton productivity across prairie saline lakes of the Great Plains (USA): a step toward deciphering patterns through lake classification models" (2009). Papers in the Earth and Atmospheric Sciences. 244.

https://digitalcommons.unl.edu/geosciencefacpub/244

This Article is brought to you for free and open access by the Earth and Atmospheric Sciences, Department of at DigitalCommons@University of Nebraska - Lincoln. It has been accepted for inclusion in Papers in the Earth and Atmospheric Sciences by an authorized administrator of DigitalCommons@University of Nebraska - Lincoln. 


\title{
Phytoplankton productivity across prairie saline lakes of the Great Plains (USA): a step toward deciphering patterns through lake classification models
}

\author{
Courtney R. Salm, Jasmine E. Saros, Sherilyn C. Fritz, Christopher L. Osburn, and \\ David M. Reineke
}

\begin{abstract}
We investigated patterns of primary production across prairie saline lakes in the central and northern Great Plains of the United States. Based on comparative lake sampling in 2004, seasonal predictors of algal primary productivity were identified within subsets of similar lakes using a combination of Akaike's information criterion (AIC) and classification and regression trees (CART). These models indicated complex patterns of nutrient limitation by nitrogen $(\mathrm{N})$, phosphorus $(\mathrm{P})$, and iron $(\mathrm{Fe})$ within different lake groups. Nutrient enrichment assays (control, $+\mathrm{Fe},+\mathrm{N},+\mathrm{P},+\mathrm{N}+\mathrm{P}$ ) were performed in spring and summer of 2006 to determine if phytoplankton in selected lakes followed predicted patterns of nutrient limitation. Both the comparative lake sampling and experimental results indicated that $\mathrm{N}$ limitation was widespread in these prairie lakes, with evidence for secondary P limitation in certain lakes. In the experiments, iron did not stimulate primary production. Our results suggest that given the diverse geochemical nature of these lakes, classification models that separate saline lakes into subsets may be an effective method for improving predictions of algal production.
\end{abstract}

Résumé : Nous avons étudié les patrons de production primaire dans des lacs salés de prairie répartis dans le centre et le nord des Grandes Plaines des États-Unis. À partir d'un échantillonnage comparatif des lacs en 2004, nous avons identifié les variables prédictives saisonnières de la production primaire des algues dans des sous-ensembles de lacs en utilisant conjointement le critère d'information d'Akaike (AIC) et des arbres de classification et de régression (CART). Ces modèles identifient des patrons complexes de limitation par les nutriments d'azote $(\mathrm{N})$, de phosphore $(\mathrm{P})$ et de fer $(\mathrm{Fe})$ dans les différents groupes de lacs. Nous avons fait des tests d'enrichissement de nutriments (témoin, $+\mathrm{Fe},+\mathrm{N},+\mathrm{P},+\mathrm{N}+\mathrm{P}$ ) au printemps et à l'été 2006 afin de déterminer si le phytoplancton dans les lacs sélectionnés suivait les patrons prédits de limitation par les nutriments. Tant l'échantillonnage comparatif des lacs que les résultats expérimentaux indiquent que la limitation par $\mathrm{N}$ est commune dans ces lacs de prairie, avec des indications d'une limitation secondaire par P dans certains lacs. Dans les expériences, le fer ne stimule pas la production primaire. Nos résultats indiquent qu'étant donné la nature géochimique diverse de ces lacs, les modèles de classification qui séparent les lacs salés en sous-ensembles peuvent être des méthodes efficaces pour améliorer les prédictions de production des algues.

[Traduit par la Rédaction]

\section{Introduction}

Prairie saline lakes are widely distributed across semi-arid regions of the world (Williams 1981) and are important habitats for migratory waterfowl and carbon sequestration (Batt et al. 1989; Euliss et al. 2006). Fossil algal records from these lakes are often used to reconstruct drought frequency and severity over time scales ranging from centuries to millennia (Cumming and Smol 1993; Laird et al. 1998; Fritz et al. 2000). However, although some of these lakes are limited by phosphorus or trace metals (Waiser and Robarts 1995; Evans and Prepas 1997), broad trends in the factors that control algal production across suites of these systems are not yet apparent (Bierhuizen and Prepas 1985; Campbell

Received 7 July 2008. Accepted 3 March 2009. Published on the NRC Research Press Web site at cjfas.nrc.ca on 20 August 2009.

J20656

Paper handled by Associate Editor Yves Prairie.

C.R. Salm. ${ }^{1,2}$ Department of Biology, University of Wisconsin - La Crosse, La Crosse, WI 54601, USA.

J.E. Saros. Climate Change Institute, University of Maine, Orono, ME 04469, USA.

S.C. Fritz. Department of Geosciences and School of Biological Sciences, University of Nebraska - Lincoln, Lincoln, NE 68588-0340,

USA.

C.L. Osburn. ${ }^{3}$ Marine Biogeochemistry Section, US Naval Research Laboratory, Washington, DC 20375, USA.

D.M. Reineke. Department of Mathematics, University of Wisconsin - La Crosse, La Crosse, WI 54601, USA.

${ }^{1}$ Corresponding author (e-mail: courtney.salm@umit.maine.edu).

${ }^{2}$ Present address: Climate Change Institute, 135 Sawyer Environmental Research Center, University of Maine, Orono, ME 04469, USA.

${ }^{3}$ Present address: Department of Marine, Earth, and Atmospheric Sciences, North Carolina State University, Raleigh, NC 27695, USA. 
and Prepas 1986). Commonly, these lakes do not follow the paradigm established for freshwater lakes (Waiser and Robarts 1995) in which spring total phosphorus (TP) concentrations predict summer chlorophyll $a$ (Chl $a$ ) concentrations (Dillon and Rigler 1974; Smith 1979). In prairie saline lakes, TP concentrations are often greater than $50 \mu \mathrm{g} \cdot \mathrm{L}^{-1}$, and total nitrogen (TN) concentrations can exceed $1000 \mu \mathrm{g} \cdot \mathrm{L}^{-1}$ (Campbell and Prepas 1986). Despite these high concentrations of nutrients, the algal biomass is lower than predicted based on freshwater models (Campbell and Prepas 1986; Robarts et al. 1992; Evans and Prepas 1997).

Several factors may account for the poor performance of the freshwater spring TP - summer Chl $a$ model in saline lakes. Although total nutrient concentrations are high, a substantial fraction of the nutrients may not be bioavailable (Waiser and Robarts 1995), particularly because concentrations of dissolved organic material (DOM) are very high in these lakes, ranging from 20 to $800 \mathrm{mg} \mathrm{C} \cdot \mathrm{L}^{-1}$ (measured as dissolved organic carbon (DOC); Curtis and Adams 1995; Evans and Prepas 1997; Arts et al. 2000). DOM can complex with nutrients and alter their bioavailability (Hessen and Tranvik 1998; Bushaw-Newton and Moran 1999; Findlay and Sinsabaugh 2003). In addition, the ionic composition and high salinity of saline lakes affects nutrient cycling and availability, as well as uptake by algae (Caraco et al. 1989; Waiser and Robarts 1995; Saros and Fritz 2000). Chlorophyll concentrations may be affected by intense zooplankton grazing on standing phytoplankton crops in saline lakes (Anderson 1958), and limited information is available on rates of primary production rather than chlorophyll concentrations alone (Armstrong et al. 1966; Hammer 1981). These conditions suggest that measuring total and dissolved nutrient pools may not provide enough information to discern the factors that drive algal production in these lakes; physiological parameters of algal production and nutrient status may be more useful in clarifying any patterns (Waiser and Robarts 1995).

An additional factor that may hinder the development of a predictive model of phytoplankton production in saline lakes is the assumption that one model and one variable can have sufficient explanatory power to model phytoplankton response in these chemically complex systems. Unlike marine systems, the dominant ions in saline lakes vary extensively (Fritz et al. 1993; Gosselin 1997), and the cycling of phosphorus and nitrogen can differ greatly, for example, between bicarbonate- and sulfate-dominated systems (Cole et al. 1986; Caraco et al. 1989). These differences suggest the need to develop a classification system to separate these diverse lakes into subsets based on similar characteristics. Lake classification has been used for a variety of applications, from assessing trophic state to managing water quality (Emmons et al. 1999; Søndergaard et al. 2005; Bulley et al. 2007).

We examined patterns of primary production in phytoplankton across a suite of lakes in the central and northern Great Plains of the United States in the spring and summer of 2004. In addition to measuring environmental parameters, physiological methods were used to assess the nutrient status of phytoplankton by measuring alkaline phosphatase activity and seston nutrient ratios. Rather than employing chloro- phyll measurements alone as in other studies, we directly measured phytoplankton primary production across all lakes via ${ }^{14} \mathrm{C}$ uptake rates. Subsequently, we tested the model predictions from the survey data in Cubitainer experiments in a set of lakes in the spring and summer of 2006.

\section{Materials and methods}

\section{Study sites}

Prairie saline $\left(>3 \mathrm{~g} \cdot \mathrm{L}^{-1}\right)$ and subsaline $\left(0.5-3 \mathrm{~g} \cdot \mathrm{L}^{-1}\right)$ lakes included in this study are located in the central (Nebraska) and northern (North Dakota, South Dakota, and Montana) Great Plains (CGP and NGP, respectively) (Fig. 1). On average, the Great Plains are characterized as semi-arid with a negative effective moisture balance (precipitation minus evapotranspiration, $P-E$ ). Land-use patterns vary across the region and include primarily cropland, rangeland, and undisturbed native grassland.

In the NGP, thousands of lakes occur east of the Missouri River; most of these are morainal depressions or dammed river valleys formed upon retreat of the Pleistocene ice margin (Bluemle and Clayton 1984). In eastern and central North Dakota and South Dakota, the majority of saline lakes are sulfate-dominated as a result of the widespread presence of pyrite in bedrock and surface deposits (Fritz et al. 1993). Major cation concentrations and proportions are highly variable. A smaller number of lakes are found in the glaciated regions of northeastern Montana - northwestern North Dakota immediately north of the Missouri River. The majority is in paleochannels of the Missouri River system and is dominated by carbonates because of inflow from shallow groundwater systems in calcareous outwash and till (Donovan 1994).

Lakes are also widespread in the Nebraska Sandhills of the CGP, a large region of Holocene eolian sands overlying Pleistocene and late-Tertiary alluvial sands and silts, which is the principal recharge area of the High Plains (Ogallala) Aquifer. Here lakes are formed by deflation and blockage of interdune valleys by eolian sands, and most lakes are thought to have formed during dry intervals during the Holocene (Loope et al. 1995; Mason et al. 1997). The majority of lakes is dominated by bicarbonate, although a small number of sulfate-enriched lakes occur. Sodium and potassium are the most abundant cations (LaBaugh 1986; Gosselin 1997).

Lakes across the NGP and CGP are topographically closed, but many are hydrologically connected to groundwater. Salinities range from 0.1 to greater than $100 \mathrm{~g} \cdot \mathrm{L}^{-1}$ (note that for simplicity, we use the term "prairie saline lakes" to refer to the entire group of lakes, recognizing that technically some of the lakes are subsaline). Lakes were selected to maximize variation in conductivity, ion composition, and nutrient concentrations. In the spring, these lakes were primarily dominated by diatoms (largely Fragilaria crotonensis and Cyclotella quillensis/meneghiniana) with some cyanobacteria (Gloeocapsa sp. and Aphanocapsa sp.). In the summer, cyanobacteria dominated the phytoplankton assemblages (Aphanizomenon sp. and Aphanocapsa sp.) with some diatoms (Cyclotella quillensis and Surirella sp.) (Salm et al. 2009). 
Fig. 1. Map of central Great Plains, USA. Ellipses indicate study sites for the 2004 survey. NGP, northern Great Plains; CGP, central Great Plains.

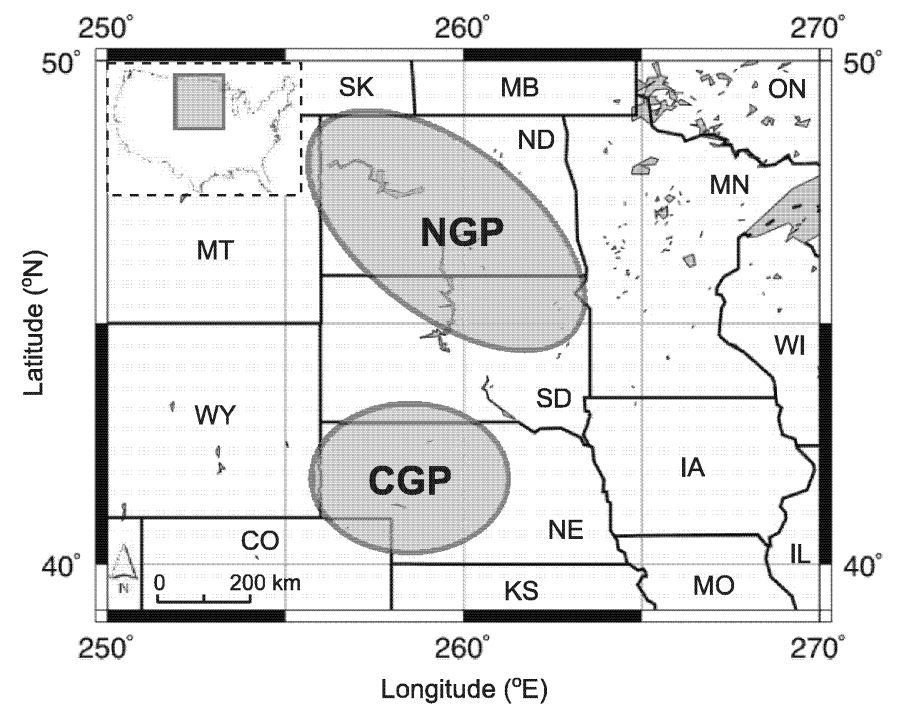

Lake sampling and model development

\section{Data collection}

Data for approximately 30 parameters were collected for lakes across the study area in both spring (24 lakes) and summer (30 lakes), including temperature, conductivity, $\mathrm{pH}$, total alkalinity, ion composition, Chl $a$, nutrients (total, particulate, and dissolved), DOM characteristics, alkaline phosphatase activity (APA), and rates of primary production. For these analyses, approximately $10 \mathrm{~L}$ of lake water were collected with a van Dorn horizontal bottle from a depth of $1 \mathrm{~m}$ in lakes that were at least $2 \mathrm{~m}$ deep and from the midpoint of the water column in lakes that were $<1 \mathrm{~m}$ deep.

Temperature and conductivity were measured with a portable conductivity meter (WTW MultiLine P4); $\mathrm{pH}$ was measured with a $\mathrm{pH}$ meter (Corning); and total alkalinity was determined by titration (American Public Health Association (APHA) 1998). Cations were measured via atomic absorption spectroscopy (Varian 220FS with a GTA-110 graphite furnace and a VGA-77 vapor generation unit), and anions were measured by ion chromatography (Dionex ICS-90).

In the field, whole water samples were collected for total $\mathrm{P}$ and total $\mathrm{N}$ and acidified with $\mathrm{H}_{2} \mathrm{SO}_{4}$. Samples for total dissolved $\mathrm{P}$, soluble reactive $\mathrm{P}$, nitrate + nitrite, and dissolved $\mathrm{Si}$ were filtered through $0.45 \mu \mathrm{m}$ Millipore membrane filters. Samples for total P, dissolved $\mathrm{P}$, and particulate $\mathrm{P}$ were first digested with potassium persulfate and measured by ascorbic acid methods (Lind 1985; APHA 1998), as were those for soluble reactive $P$. Total $N$ was measured by alkaline potassium persulfate digestion (D'Elia et al. 1977) and the ultraviolet (UV) absorption method (APHA 1998), and nitrate + nitrite $\mathrm{N}$ was determined by the hydrazine reduction method (Downes 1978). Dissolved Si was measured following the methods of Wetzel and Likens (1991). Water was also filtered through $0.7 \mu \mathrm{m}$ glassfiber filters (Whatmann $\mathrm{GF} / \mathrm{F}$ ) for analysis of $\mathrm{Chl} a$, as well as particulate carbon and nitrogen analyses (in duplicate). Filters were collected onto Petri dishes and either wrapped in foil and frozen ( $\mathrm{Chl} a$ ) or refrigerated (particulate $\mathrm{C}$ and $\mathrm{N}$ ) until processing. Chlorophyll was analyzed spectrophotometrically after pigment extraction with $90 \%$ acetone (Varian Cary-50 UV-VIS Spectrophotometer; APHA 1998) within two weeks of collection to maintain sample integrity. Filters for particulate $\mathrm{C}$ and $\mathrm{N}$ were fumed with concentrated $\mathrm{HCl}$ in a glass desiccator and measured by combustion and gas chromatography with an elemental analyzer (Costech).

Dissolved iron was quantified in samples that were filtered through $0.45 \mu \mathrm{m}$ Millipore membrane filters and acidified at the time of collection. Total recoverable iron was determined on separate acidified samples prepared by mixing unfiltered lake water with hydrochloric acid and nitric acid to improve the solubility of iron during digestion. Samples were covered and digested overnight $(\sim 12 \mathrm{~h})$ at $90{ }^{\circ} \mathrm{C}$ on a hotplate and diluted in $1 \%$ nitric acid prior to analysis. Samples for total and dissolved iron were analyzed with an inductively coupled plasma mass spectrometer (GV Instruments Platform XS). Total iron was quantified based on the response of ${ }^{56} \mathrm{Fe}$. Potential interferences were monitored in samples and blanks fortified with these elements, and Indium was added to all samples and standards to monitor for additional matrix effects. The method detection limit was $1.0 \mathrm{ppb}$.

Samples for DOM characterization were prefiltered through $0.2 \mu \mathrm{m}$ pore-size membranes before analysis. DOC concentration $\left(\mathrm{mg} \mathrm{C} \cdot \mathrm{L}^{-1}\right.$ ) was measured by wet chemical oxidation on an OI Analytical 1010 TOC analyzer, following the recommendations of Osburn and St. Jean (2007) for high-salinity samples. Sodium persulfate $\left(450 \mathrm{~g} \cdot \mathrm{L}^{-1}\right.$; cleaned by heating to a near-boil and then rapidly cooling) was added to the reactor and allowed to react for $10 \mathrm{~min}$, converting all DOC to $\mathrm{CO}_{2}$. The $\mathrm{CO}_{2}$ was quantified by nondispersive IR detection and calibrated to potassium biphthalate standards over the range of $1-100 \mathrm{mg} \mathrm{C} \cdot \mathrm{L}^{-1}$. Sample volumes of $100-2000 \mu \mathrm{L}$ were injected to stay within this calibration range.

Absorption of water samples was measured from 250 to $650 \mathrm{~nm}$ on a dual-beam spectrophotometer (Shimadzu UV1601) against Milli-Q water in $1 \mathrm{~cm}$ cuvets due to the strong absorbance of these samples. Raw absorbance was converted to absorption coefficients:

$$
a(\lambda)=A(\lambda) \times 2.303 / D
$$

where $A(\lambda)$ is the raw absorbance of the sample at wavelength $\lambda$, and $D$ is the pathlength of the $1 \mathrm{~cm}$ cuvet (in metres) (Kirk 1994). The constant of 2.303 converts from the natural logarithm. The ratio of absorption at 250$365 \mathrm{~nm}$ has been used to observe relative changes in molecular weight of DOC (De Haan and De Boer 1987). An increase in the ratio indicates a decrease in molecular weight.

Bulk alkaline phosphatase activity was measured in the field with the 4-methylumbelliferyl phosphate method (Hill et al. 1968) on a field fluorometer (Turner Designs Model 10-AU Field Fluorometer). Bulk APA:Chl a ratios were used to normalize enzyme activity to the amount of algal biomass.

Rates of primary productivity in each lake were assessed using a modified light-dark bottle ${ }^{14} \mathrm{C}$ uptake assay (Wetzel and Likens 1991). Bottles (300 mL) were incubated under a 
suspended light bank (Freshwater AquaLight by Coralife, $\sim 450 \mu \mathrm{E} \cdot \mathrm{cm}^{-2} \cdot \mathrm{s}^{-1}$ ) in a water bath held at a temperature consistent with ambient seasonal lake conditions (2004: spring, $15^{\circ} \mathrm{C}$; summer, $20{ }^{\circ} \mathrm{C}$ ). We chose this approach, rather than in situ incubations in each lake, to maintain similar light and temperature conditions across all lakes. Bottles were filled with lake water prescreened through $212 \mu \mathrm{m}$ Nitex mesh to remove large grazers. During the summer, when colonial cyanobacteria populations were present in lakes, prefiltering was not possible for some lakes. In these instances, grazers were handpicked from bottles with a pipette. Each bottle was inoculated with $0.5-2.0 \mathrm{~mL} \mathrm{NaH}{ }^{14} \mathrm{CO}_{3}$ solution (Perkin Elmer, $\left.1 \mu \mathrm{Ci} \cdot \mathrm{mL}^{-1}\right)$ and incubated onshore for $3 \mathrm{~h}$ at some point between 0900 and $1500 \mathrm{~h}$ (within the diurnal period of maximum algal productivity). After incubation, two aliquots (the size of which depended on algal densities) were collected from each bottle on $0.45 \mu \mathrm{m}$ Millipore HA filters, which were dried in a desiccator overnight and stored in a cool, dry location until processing in the laboratory. Filters were fumed with concentrated $\mathrm{HCl}$ in a glass desiccator to remove residual inorganic ${ }^{14} \mathrm{C}$ and carbonates. They were dissolved in $10 \mathrm{~mL}$ of Filter-Count scintillation cocktail (Perkin Elmer) and read on a scintillation counter (Beckman Coulter LS 6500; 32768 channels with $0.06 \mathrm{keV}$ per channel resolution), with primary production rates calculated according to Wetzel and Likens (1991).

\section{Data analysis}

Values for all variables except $\mathrm{pH}$, seston ratios, and $a_{250}: a_{365}$ were $\log _{10}$-transformed to correct for unequal variance after Levene's homogeneity of variance test, and simple and stepwise multiple regression were used to identify predictors of primary production $(\alpha=0.05)$. In addition to these methods, Akaike's information criterion (AIC; Burnham and Anderson 2002) was used to explore how multiple factors may control primary production across all lakes in the data set. Although a priori hypotheses are strongly suggested when using AIC, in cases such as this when it is difficult to formulate reasonable a priori models, AIC may be used in conjunction with secondary studies to confirm important predictor variables (Burnham and Anderson 2002). A program for running AIC analyses in SAS (version 9.1; SAS Institute Inc., Cary, North Carolina) was written by Episystems, Inc. (St. Paul, Minnesota) and used to analyze the spring and summer comparative lake sampling data. The best set of approximating models was found from a larger set of candidate models by selecting those with the lowest AIC. It has been suggested that models for which the AIC value is within 4 units of the lowest would constitute an approximate $95 \%$ confidence set of top models (Burnham and Anderson 2002); thus this criterion was used to determine which models were retained, parameter weights, and modelaveraged parameter estimates.

Exploratory classification models also were developed with classification and regression trees (CARTs; De'ath and Fabricius 2000) using the program $\mathrm{R}$ (version 2.1.1; http:// www.r-project.org/), with the rate of primary production as the predictor variable for regression trees and phosphorus limitation status (severely limited or not limited) as the predictor variable for classification trees. An APA : Chl $a$ value above 0.005 is considered indicative of severe $\mathrm{P}$ limitation (Healey and Hendzel 1980); hence this was used as the dividing value between lakes that were potentially P-limited (APA : Chl $a>0.005$ ) or not (APA : Chl $a \leq 0.005$ ). Simple regressions were then performed in SPSS (version 11.5 for Windows; SPSS Inc., Chicago, Illinois) to identify parameters controlling primary production within each of the resulting groups.

\section{Experiments and model testing}

\section{Experimental design}

Using the groups identified in the CART analyses (see Results below), nutrient enrichment experiments were conducted in spring and summer 2006 as a test of these models. Assays were similar in spring and summer, with five treatments created with the following additions: control (no nutrient addition), Fe, $\mathrm{N}, \mathrm{P}$, and $\mathrm{N}+\mathrm{P}(n=3)$. For the spring and summer experiments, a subset of two or three lakes was chosen from within each group identified by the CART analyses. Water from each lake was filtered through a $212 \mu \mathrm{m}$ mesh to remove large zooplankton and incubated in $4 \mathrm{~L}$ Cubitainers (VWR TraceClean ${ }^{\mathrm{TM}}$ Cubitainer $^{\mathrm{TM}}$ containers, made of low-density polyethylene) in Coldwater Lake at approximately $0.5 \mathrm{~m}$ depth in the spring $\left(15{ }^{\circ} \mathrm{C}\right)$ and just below the surface in the summer $\left(20{ }^{\circ} \mathrm{C}\right)$. Appropriate iron $\left(11.7 \mu \mathrm{mol} \mathrm{Fe} \cdot \mathrm{L}^{-1}\right.$ in the form of $\mathrm{FeCl}_{3} \cdot 6 \mathrm{H}_{2} \mathrm{O}$, added along with $11.7 \mu \mathrm{mol}$ EDTA $\left.\cdot \mathrm{L}^{-1}\right)$, nitrogen $\left(18 \mu \mathrm{mol} \mathrm{N} \cdot \mathrm{L}^{-1}\right.$ in the form of $\mathrm{NaNO}_{3}$ ), and phosphorus $\left(5 \mu \mathrm{mol} \mathrm{P} \cdot \mathrm{L}^{-1}\right.$ in the form of $\mathrm{NaH}_{2} \mathrm{PO}_{4}$ ) additions were made to each Cubitainer. Transmission scans of Cubitainer plastic on a spectrophotometer (Varian Cary-50 UV-VIS Spectrophotometer) indicated that for the visible spectrum, approximately $60 \%-$ $75 \%$ of ambient light was allowed through the plastic, whereas at lower wavelengths $(\sim 300 \mathrm{~nm}), 40 \%-50 \%$ of ambient light was allowed through. For each Cubitainer, rates of primary production $\left({ }^{14} \mathrm{C}\right.$ uptake assay) were measured initially and 3 days after nutrient additions, because preliminary laboratory experiments indicated that, based on daily measurements over a 7-day period, the greatest changes in production rates occurred on day 3 (data not shown). One light bottle was analyzed for each Cubitainer, and two darkbottle replicates were analyzed for each lake. The dark-bottle replicates were taken from a random control Cubitainer and a random $\mathrm{N}+\mathrm{P}$ Cubitainer for each lake to assess whether the higher biomass in nutrient addition treatments affected the ${ }^{14} \mathrm{C}$ measurements. Previous use of this method during the comparative lake sampling in 2004 showed very little variation among dark-bottle replicates.

\section{Data analysis}

Results from these experiments were statistically analyzed using analysis of variance (ANOVA) in SPSS (version 11.5 for Windows; SPSS Inc., Chicago, Illinois) to determine if rates of primary production were significantly different among treatments $(\alpha=0.05)$. Levene's homogeneity of variance test was used to check for equal variances, and rates of primary production were $\log _{10}$-transformed to correct for unequal variances. Tukey's post-hoc analysis was also used to compare mean values across treatments. 


\section{Results}

\section{Lake sampling and model development}

Rates of primary production were generally higher across lakes in summer compared with spring (Table 1). Regional differences among lakes also were evident, as CGP lakes had much higher rates of productivity than those of the NGP based on the ${ }^{14} \mathrm{C}$ uptake assays (spring average rates of primary productivity: CGP, $263.4 \mathrm{mg} \mathrm{C} \cdot \mathrm{m}^{-3} \cdot \mathrm{h}^{-1}$; NGP, $33.0 \mathrm{mg} \mathrm{C} \cdot \mathrm{m}^{-3} \cdot \mathrm{h}^{-1}$; summer average rates: CGP, $526.5 \mathrm{mg}$ $\mathrm{C} \cdot \mathrm{m}^{-3} \cdot \mathrm{h}^{-1}$; NGP, $\left.124.9 \mathrm{mg} \mathrm{C} \cdot \mathrm{m}^{-3} \cdot \mathrm{h}^{-1}\right)$. CGP lakes had high concentrations of nutrients and DOC and were shallow $(<1 \mathrm{~m})$ and very turbid, making filtration difficult (only possible to filter $1-2 \mathrm{~mL}$ at most through $0.45 \mu \mathrm{m}$ filters). Some of these systems dried out in the summer, preventing parallel seasonal studies. Given these difficulties with the CGP lakes, we examined patterns in the full data set of lakes, as well as the subset of lakes $(n=18)$ found in the NGP alone.

Simple regressions between rates of primary production and key nutrients did not indicate strong limitation by a single nutrient (Table 2), with the exception of $\mathrm{NO}_{3}^{-}$for all lakes in the spring $\left(R^{2}=0.519, F=28.08, \mathrm{df}=1,22, p<\right.$ $0.001)$. Other low $R^{2}$ but significant simple regressions with nutrient parameters included total $\mathrm{P}\left(R^{2}=0.306, F=9.718\right.$, $\mathrm{df}=1,22, p=0.005)$ and total $\mathrm{N}\left(R^{2}=0.202, F=5.561, \mathrm{df}=\right.$ $1,22, p<0.028)$ for all lakes in the spring, total $\mathrm{P}\left(R^{2}=\right.$ $0.316, F=12.951$, df $=1,28, p<0.001)$ and total $\mathrm{N}\left(R^{2}=\right.$ $0.168, F=5.634, \mathrm{df}=1,28, p=0.025)$ for all lakes in the summer, and total $\mathrm{N}\left(R^{2}=0.238, F=4.985, \mathrm{df}=1,16, p=\right.$ $0.040)$ for NGP lakes only.

Multiple regressions revealed variable predictors of primary production by season and region. For the spring, $\mathrm{NO}_{3}{ }^{-}$ was the only variable selected by stepwise regression for all lakes $\left(R^{2}=0.519, F=22.66, \mathrm{df}=1,21, p<0.001\right)$, with a positive relationship between this parameter and primary production rates. This relationship was not found for the subset of NGP lakes alone, in which no variables were significant predictors of primary production. In the summer, stepwise selection indicated $\mathrm{C}: \mathrm{P}$ and dissolved $\mathrm{Fe}$ as the best predictors for all lakes $\left(R^{2}=0.606, F=20.75\right.$, df $=$ $1,28, p<0.001$ ), and absorptivity at $350 \mathrm{~nm}$ (indicative of chromophoric dissolved organic matter) for NGP lakes alone $\left(R^{2}=0.311, F=7.23, \mathrm{df}=1,16, p=0.016\right)$. These parameters were positively correlated to rates of primary production.

AIC models were developed separately for spring and summer; within each season, models for all lakes, as well as just the NGP lakes, were generated (Table 3). All of the models suggested multivariate control over primary production across these lakes. Each model also identified one or two of the strongest variables (with a predictor weight close to or equal to 1) correlated with rates of primary production. Looking across the variables with the highest predictor weights, the AIC approach identified dissolved $\mathrm{Fe}$ and $\mathrm{NO}_{3}{ }^{-}$ as the best predictors of primary production in spring for all lakes, and calcium, dissolved Fe, and TP for the NGP lakes subset. In the summer, the best predictors for all lakes were $\mathrm{C}: \mathrm{P}$ and ions $\left(\mathrm{Cl}^{-}, \mathrm{K}^{+}, \mathrm{Na}^{+}\right)$, and phosphorus parameters (TP, N:P, and SRP) for the NGP lakes. Thus, results indi- cated that the limiting factors for rates of primary production differed regionally as well as seasonally.

In the CART analyses, spring regression trees showed a split, with $\mathrm{NO}_{3}{ }^{-}$as the only branching variable (Fig. 2). This separation appeared to be related to geographic distribution, as high nitrate lakes $\left(\left[\mathrm{NO}_{3}{ }^{-}\right]>17.5 \mu \mathrm{g} \cdot \mathrm{L}^{-1}\right)$ were located in the CGP and low nitrate lakes $\left(\left[\mathrm{NO}_{3}{ }^{-}\right]<17.5 \mu \mathrm{g} \cdot \mathrm{L}^{-1}\right)$ were located in the NGP. Classification further split the NGP lakes by APA:Chl $a$ ratio. Within the three groups delineated in Fig. 2, simple regressions did not yield any significant predictor variables for rates of primary production at the $\alpha=0.05$ level. However, regressions for high $\mathrm{NO}_{3}$ lakes from the CGP showed a positive correlation between primary production and maximum depth $\left(R^{2}=0.5000, F=\right.$ $4.01, \mathrm{df}=1,4, p=0.12$ ), which may be a reflection of the very high turbidity and greater potential light limitation in the shallower lakes of the CGP. Low $\mathrm{NO}_{3}^{-}$, low APA: Chl $a$ lakes (designated SPR-N to reflect potential $\mathrm{N}$ limitation) showed a positive correlation between primary production and N:P ratios $\left(R^{2}=0.3623, F=3.41, \mathrm{df}=1,6, p=0.11\right)$, and low $\mathrm{NO}_{3}^{-}$, high APA : Chl $a$ lakes (designated SPR-NP to reflect potential $\mathrm{N}$ and $\mathrm{P}$ co-limitation) showed a positive correlation between primary production and unfiltered APA rates $\left(R^{2}=0.3323, F=3.98, \mathrm{df}=1,8, p=0.08\right)$ such that lakes in this subset with higher APA rates were more productive.

Summer regression trees showed a split with C:P seston ratios (Fig. 3). The high $\mathrm{C}: \mathrm{P}$ group $(\mathrm{C}: \mathrm{P}>3591)$ contained most of the highly productive CGP lakes, whereas the group with lower $C: P$ values $(C: P<3591)$ had lower rates of primary production on average and included NGP lakes and the remainder of the CGP lakes. The split was at an extremely high C:P ratio, outside of typical ranges for seston ratios for freshwater lakes (Elser et al. 2000; Sterner and Elser 2002), and generally follows geographic distribution as in the spring. When CGP lakes were excluded from the regression tree, there were no branches within the NGP lakes. These data suggested that phosphorus gradients were involved in controlling primary production during the summer, so APA:Chl $a$ classification trees were used again for the NGP lakes alone. The main branching factor in this subset of lakes was soluble reactive P (SRP), with a branch point of $25 \mu \mathrm{g} \cdot \mathrm{L}^{-1}$. Simple regressions for the higher SRP group (designated SUM-N) showed a positive correlation between primary production rates and $\mathrm{N}: \mathrm{P}$ ratios $\left(R^{2}=0.38, F=\right.$ $5.55, \mathrm{df}=1,9, p=0.043)$. The regression for the lower SRP group (designated SUM-P) between rate of primary production and total $\mathrm{P}$ was significant $\left(R^{2}=0.78, F=17.5, \mathrm{df}=\right.$ $1,5, p=0.009$ ).

\section{Spring experimental results}

For the spring experiment, three lakes were selected from the SPR-NP group (Alkaline Lake, Coldwater Lake, and Free People Lake), as well as two from the SPR-N group (East Devils Lake and Stink Lake). The nutrient treatments affected primary production rates in four of the five lakes tested (Fig. 4; Table 4). Of the SPR-NP lakes predicted to respond to both $\mathrm{N}$ and $\mathrm{P}$, rates in Alkaline Lake $(F=30.6$, $\mathrm{df}=4,10, p<0.001)$ and Coldwater Lake $(F=75.6, \mathrm{df}=$ $4,10, p<0.001)$ increased in the $\mathrm{N}$ treatment, with additional increases in the $\mathrm{N}+\mathrm{P}$ treatments. Free People Lake 
Table 1. Summary of 2004 spring and summer survey data used in analyses.

\begin{tabular}{|c|c|c|c|c|}
\hline Parameter & Units & All lakes & CGP only & NGP only \\
\hline \multicolumn{5}{|l|}{ Spring } \\
\hline Primary production rate & $\mathrm{mg} \mathrm{C} \cdot \mathrm{m}^{-3} \cdot \mathrm{h}^{-1}$ & $91(4-452)$ & $263(138-452)$ & $33(4-102)$ \\
\hline Chl $a$ & $\mu g \cdot L^{-1}$ & $76(1-1060)$ & $225(2-1060)$ & $10(1-22)$ \\
\hline$Z_{\max }$ & $\mathrm{m}$ & $4.1(1.0-13.0)$ & $1.6(1-2.5)$ & $5.1(1.0-13.0)$ \\
\hline Temperature & ${ }^{\circ} \mathrm{C}$ & $15(9-22)$ & $18(16-22)$ & $13(9-17)$ \\
\hline $\mathrm{pH}$ & & $9.04(7.94-10.43)$ & $9.61(8.89-10.43)$ & $8.79(7.94-9.42)$ \\
\hline Total alkalinity & $\mathrm{mg} \mathrm{CaCO}{ }_{3} \cdot \mathrm{L}^{-1}$ & $4150(200-54100)$ & $11795(300-54100)$ & $752(200-2030)$ \\
\hline DOC & $\mathrm{mg} \cdot \mathrm{L}^{-1}$ & $32(18-82)$ & - & $32(18-82)$ \\
\hline Total P & $\mu g \cdot L^{-1}$ & $1269(19-15860)$ & $3863(243-15860)$ & $116(19-273)$ \\
\hline Total dissolved $\mathrm{P}$ & $\mu \mathrm{g} \cdot \mathrm{L}^{-1}$ & $762(14-10866)$ & $2276(47-10866)$ & $89(14-242)$ \\
\hline Soluble reactive $\mathrm{P}$ & $\mu g \cdot L^{-1}$ & $454(3-5816)$ & $1345(18-5816)$ & $57(3-199)$ \\
\hline Total N & $\mu \mathrm{g} \cdot \mathrm{L}^{-1}$ & $5145(587-23297)$ & $12380(997-23297)$ & $1930(587-4379)$ \\
\hline Nitrate + nitrite & $\mu \mathrm{g} \cdot \mathrm{L}^{-1}$ & $31(1-147)$ & $83(69-147)$ & $8(1-18)$ \\
\hline Dissolved Si & $\mu \mathrm{g} \cdot \mathrm{L}^{-1}$ & $14(0.2-93)$ & $43(7-93)$ & $1(0.2-2.5)$ \\
\hline Total Fe & $\mu g \cdot L^{-1}$ & $737(39-8584)$ & $2308(141-8584)$ & $126(39-574)$ \\
\hline Dissolved Fe & $\mu \mathrm{g} \cdot \mathrm{L}^{-1}$ & $41(3-289)$ & $82(13-289)$ & $22(4-88)$ \\
\hline $\mathrm{C}: \mathrm{N}$ & & $9.6(6.1-15.1)$ & - & $9.6(6.1-15.1)$ \\
\hline $\mathrm{C}: \mathrm{P}$ & & $231(79-579)$ & - & $231(79-579)$ \\
\hline $\mathrm{N}: \mathrm{P}$ & & $24(11-41)$ & - & $24(11-41)$ \\
\hline APA:Chl $a$ & & $0.0484(0.0000-0.4044)$ & - & $0.0484(0.0000-0.4044)$ \\
\hline Conductivity & $\mathrm{mS} \cdot \mathrm{cm}^{-1}$ & $9.86(0.58-72.81)$ & $18.24(0.58-72.81)$ & $6.13(1.39-16.20)$ \\
\hline $\mathrm{Ca}^{2+}$ & $\mathrm{mg} \cdot \mathrm{L}^{-1}$ & $59(4-338)$ & $32(4-127)$ & $69(7-338)$ \\
\hline $\mathrm{Mg}^{2+}$ & $\mathrm{mg} \cdot \mathrm{L}^{-1}$ & $179(0-1729)$ & $18(0-65)$ & $242(31-1729)$ \\
\hline $\mathrm{Na}^{+}$ & $\mathrm{mg} \cdot \mathrm{L}^{-1}$ & $1657(72-17569)$ & $4123(72-17569)$ & $698(101-2034)$ \\
\hline $\mathrm{K}^{+}$ & $\mathrm{mg} \cdot \mathrm{L}^{-1}$ & $567(14-5528)$ & $1842(30-5528)$ & $71(14-188)$ \\
\hline $\mathrm{Cl}^{-}$ & $\mathrm{mg} \cdot \mathrm{L}^{-1}$ & $419(11-4422)$ & $788(11-4422)$ & $255(18-931)$ \\
\hline $\mathrm{SO}_{4}^{3-}$ & $\mathrm{mg} \cdot \mathrm{L}^{-1}$ & $2017(8-10842)$ & $1186(8-6138)$ & $2386(193-10842)$ \\
\hline Filtered APA rate & $\mathrm{nmol} \cdot \mathrm{L}^{-1} \mathrm{MUP} \cdot \mathrm{h}^{-1}$ & $76.9(0.0-417.0)$ & - & $76.9(0.0-278.0)$ \\
\hline Unfiltered APA rate & $\mathrm{nmol} \cdot \mathrm{L}^{-1} \mathrm{MUP} \cdot \mathrm{h}^{-1}$ & $31.8(17.6-82.2)$ & - & $31.8(17.6-82.2)$ \\
\hline$a_{350}$ & $\mathrm{~m}^{-1}$ & $23(2-124)$ & $69(25-124)$ & $8(2-13)$ \\
\hline$a_{250}: a_{365}$ & & $24(11-71)$ & $30(14-71)$ & $22(11-45)$ \\
\hline \multicolumn{5}{|l|}{ Summer } \\
\hline Primary production rate & $\mathrm{mg} \mathrm{C} \cdot \mathrm{m}^{-3} \cdot \mathrm{h}^{-1}$ & $286(11-1747)$ & $527(11-1747)$ & $125(15-544)$ \\
\hline Chl $a$ & $\mu \mathrm{g} \cdot \mathrm{L}^{-1}$ & $118(3-1613)$ & $237(3-1613)$ & $39(6-197)$ \\
\hline$Z_{\max }$ & $\mathrm{m}$ & $3.7(1.0-13.0)$ & $1.6(1.0-2.6)$ & $5.1(1.0-13.0)$ \\
\hline Temperature & ${ }^{\circ} \mathrm{C}$ & $19(15-24)$ & $20(18-24)$ & $18(15-23)$ \\
\hline $\mathrm{pH}$ & & $9.36(8.41-10.66)$ & $9.91(8.88-10.66)$ & $9.00(8.41-10.14)$ \\
\hline Total alkalinity & $\mathrm{mg} \mathrm{CaCO} 3 \cdot \mathrm{L}^{-1}$ & $3725(190-38000)$ & $8121(231-38000)$ & $794(190-2550)$ \\
\hline DOC & $\mathrm{mg} \cdot \mathrm{L}^{-1}$ & $161(14-1512)$ & $358(48-1512)$ & $29(14-91)$ \\
\hline Total P & $\mu \mathrm{g} \cdot \mathrm{L}^{-1}$ & $4922(25-71622)$ & $12087(89-71622)$ & $145(25-329)$ \\
\hline Total dissolved $\mathrm{P}$ & $\mu \mathrm{g} \cdot \mathrm{L}^{-1}$ & $810(11-12328)$ & $1873(19-12328)$ & $102(11-315)$ \\
\hline Soluble reactive $\mathrm{P}$ & $\mu \mathrm{g} \cdot \mathrm{L}^{-1}$ & $475(7-5874)$ & $1085(7-5874)$ & $68(7-271)$ \\
\hline Total N & $\mu g \cdot L^{-1}$ & $6042(708-23020)$ & $11246(1689-23020)$ & $2573(708-3500)$ \\
\hline Nitrate + nitrite & $\mu \mathrm{g} \cdot \mathrm{L}^{-1}$ & $8(0-55)$ & $11(0-55)$ & $5(1-18)$ \\
\hline Dissolved Si & $\mu \mathrm{g} \cdot \mathrm{L}^{-1}$ & $23(1-156)$ & $43(2-156)$ & $9(1-26)$ \\
\hline Total Fe & $\mu \mathrm{g} \cdot \mathrm{L}^{-1}$ & $452(24-4119)$ & $925(24-4119)$ & $136(24-516)$ \\
\hline Dissolved Fe & $\mu \mathrm{g} \cdot \mathrm{L}^{-1}$ & $31(0-190)$ & $26(0-112)$ & $34(3-190)$ \\
\hline $\mathrm{C}: \mathrm{N}$ & & $12.2(6.3-33.6)$ & $17.2(8.5-33.6)$ & $8.9(6.3-18.7)$ \\
\hline $\mathrm{C}: \mathrm{P}$ & & $2008(131-8803)$ & $4581(432-8803)$ & $292(131-1000)$ \\
\hline $\mathrm{N}: \mathrm{P}$ & & $129(16-705)$ & $273(52-705)$ & $32(16-53)$ \\
\hline APA:Chl $a$ & & $0.0761(0.00002-0.9667)$ & $0.1264(0.00002-0.9667)$ & $0.0426(0.00002-0.3309)$ \\
\hline Conductivity & $\mathrm{mS} \cdot \mathrm{cm}^{-1}$ & $10.39(0.53-82.10)$ & $16.30(0.53-82.10)$ & $6.45(1.51-16.60)$ \\
\hline $\mathrm{Ca}^{2+}$ & $\mathrm{mg} \cdot \mathrm{L}^{-1}$ & $45(4-350)$ & $11(4-22.1)$ & $67(5-350)$ \\
\hline $\mathrm{Mg}^{2+}$ & $\mathrm{mg} \cdot \mathrm{L}^{-1}$ & $168(0-1889)$ & $20(0-62)$ & $266(32-1889)$ \\
\hline $\mathrm{Na}^{+}$ & $\mathrm{mg} \cdot \mathrm{L}^{-1}$ & $1753(74-21073)$ & $3088(74-21073)$ & $862(101-2716)$ \\
\hline $\mathrm{K}^{+}$ & $\mathrm{mg} \cdot \mathrm{L}^{-1}$ & $743(15-7954)$ & $1728(35-7954)$ & $86(15-268)$ \\
\hline $\mathrm{Cl}^{-}$ & $\mathrm{mg} \cdot \mathrm{L}^{-1}$ & $473(13-6394)$ & $861(13-6394)$ & $235(17-876)$ \\
\hline $\mathrm{SO}_{4}^{3-}$ & $\mathrm{mg} \cdot \mathrm{L}^{-1}$ & $2223(5-12728)$ & $1459(5-9176)$ & $2690(231-12728)$ \\
\hline Filtered APA rate & $\mathrm{nmol} \cdot \mathrm{L}^{-1} \mathrm{MUP} \cdot \mathrm{h}^{-1}$ & $2180.1(2.5-58734.1)$ & $5267.0(2.5-58734.1)$ & $122.1(2.8-904.8)$ \\
\hline Unfiltered APA rate & $\mathrm{nmol} \cdot \mathrm{L}^{-1} \mathrm{MUP} \cdot \mathrm{h}^{-1}$ & $4083.1(5.8-98604.5)$ & $8979.0(6.8-98604.5)$ & $819.1(5.8-9848.1)$ \\
\hline$a_{350}$ & $\mathrm{~m}^{-1}$ & $20(2-79)$ & $38(11-79)$ & $8(2-22)$ \\
\hline$a_{250}: a_{365}$ & & $26(11-87)$ & $37(14-87)$ & $20(11-38)$ \\
\hline
\end{tabular}

Note: Values are expressed as mean with range in parentheses. Seston ratios are reported on a molar basis. CGP, central Great Plains; NGP, northern Great Plains; - , parameter not measured for these sites. APA, alkaline phosphatase activity; MUP, 4-methylumbelliferyl phosphate; $a_{250}, a_{350}$, and $a_{365}$, absorptivity at 250,350 , and $365 \mathrm{~nm}$, respectively. 
Table 2. $R^{2}$ values for simple regressions of rates of primary productivity versus selected nutrient parameters.

\begin{tabular}{llllll}
\hline & \multicolumn{3}{l}{ Spring } & & \multicolumn{2}{l}{ Summer } \\
\cline { 2 - 3 } \cline { 5 - 6 } Parameter & All lakes & NGP only & & All lakes & NGP only \\
\hline Total P & $0.306^{a}$ & 0.034 & & $0.316^{a}$ & 0.198 \\
Dissolved P & 0.072 & 0.095 & & 0.011 & 0.099 \\
SRP & 0.030 & 0.150 & & 0.062 & 0.055 \\
Total N & $0.202^{a}$ & 0.008 & & $0.168^{a}$ & $0.238^{a}$ \\
Nitrate + nitrite & $0.561^{a}$ & 0.103 & & 0.077 & 0.001 \\
\hline
\end{tabular}

Note: NGP, northern Great Plains; SRP, soluble reactive phosphorus.

${ }^{a} p<0.05$

Table 3. $\triangle \mathrm{AIC}_{\mathrm{c}}$ values describe model fit, with smaller values indicating better fit: $(a)$ summary of primary productivity models developed with Akaike's information criterion (AIC) for 2004 survey data; $(b)$ summary of top predictor variables from AIC models of 2004 survey data.

(a) Summary of primary productivity models developed with AIC for 2004 survey data.

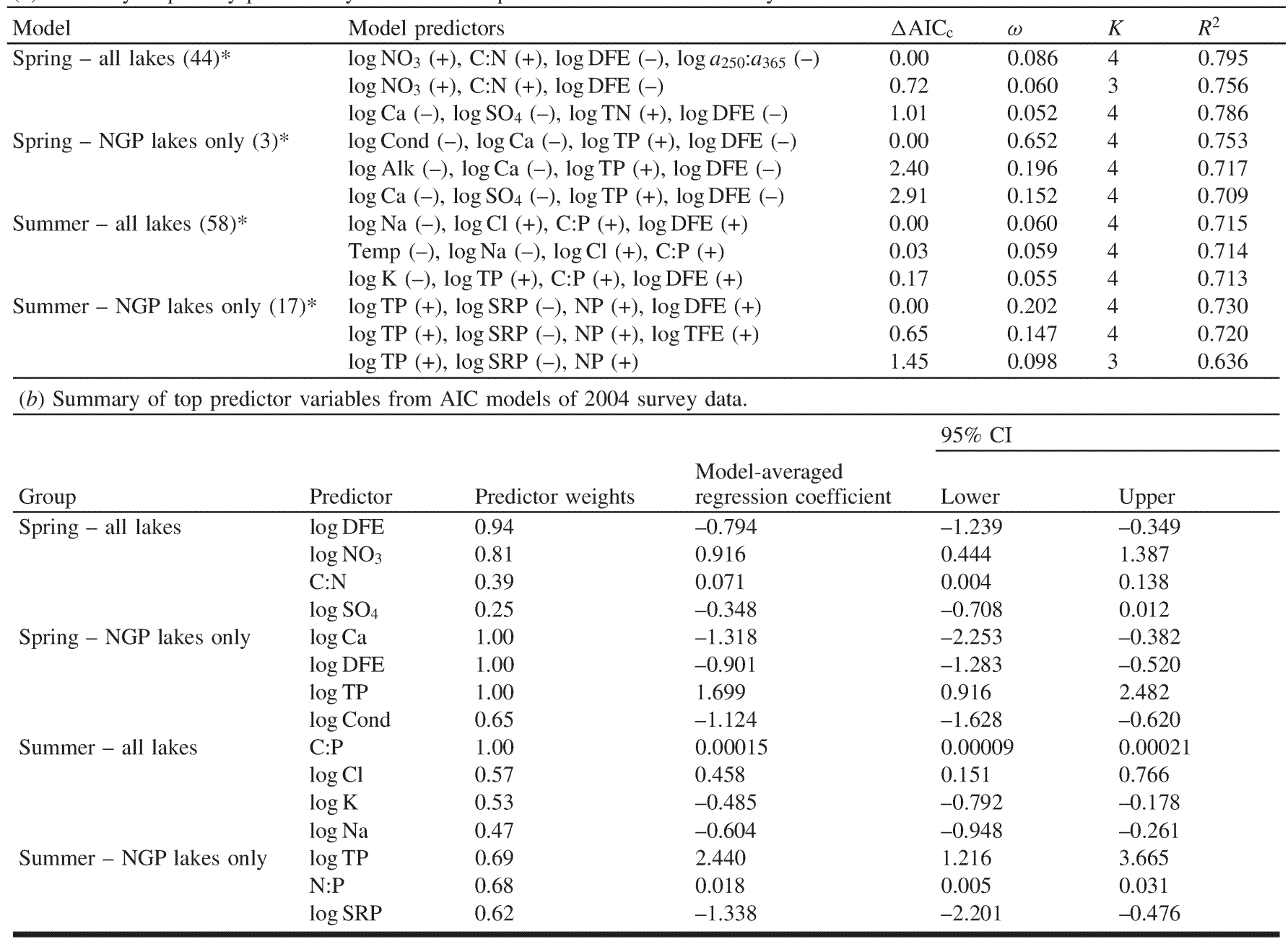

Note: Akaike weights, denoted as $\omega$, describe the probability that the model is the best model generated, and $K$ is the number of estimable parameters in the model. Predictor weights indicate the predictive strength of the variable, with values near 1 having the strongest predictive weight. Asterisk $(*)$ indicates the number of models with $\triangle \mathrm{AIC}_{\mathrm{c}}<4$, which were used to compute the Akaike weights. CI, confidence interval; DFE, dissolved Fe; TN, total $\mathrm{N}$; Cond, conductivity; TP, total P; Alk, alkalinity; Temp, temperature; SRP, soluble reactive phosphorus; TFE, total Fe.

only responded to the $\mathrm{N}$ treatment $(F=81.3$, df $=4,10, p<$ $0.001)$, with no additional increase in the combination treatment of $\mathrm{N}+\mathrm{P}$. It should be noted, however, that Free People Lake was classified as a SPR-NP lake based on 2004 data, but in 2006, the APA: Chl a ratio was below 0.005, moving it to the SPR-N group (Table 5). For the SPR-N group, predicted to respond to $\mathrm{N}$ alone, the rate of production only increased in East Devil's Lake in the $\mathrm{N}$ addition 
Fig. 2. Lake classification for spring 2004 survey data. Nitrate, shown at the top of the figure, was identified as the main splitting variable based on an initial regression tree with primary production as the response metric. On the lower left portion of the figure, NGP lakes were further examined for P limitation with APA : Chl $a$ ratios identified as the splitting variable based on a classification tree with P-limitation category (no P limitation or severe limitation) as the response variable. Simple regressions were performed within each subset of lakes, although no regressions were statistically significant $(\alpha=0.05$ ). Abbreviations: CGP, central Great Plains; NGP, northern Great Plains; SPR-N, potentially N-limited lakes; SPR-NP, potentially N and P co-limited lakes.

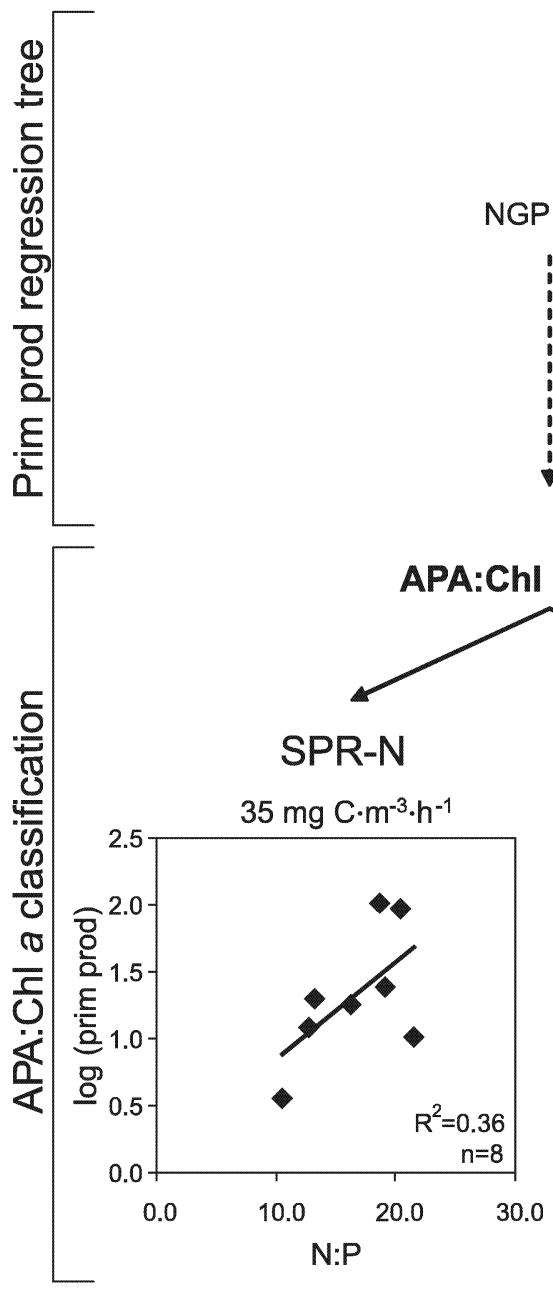

$(F=96.5, \mathrm{df}=4,10, p<0.001)$. Although there were significant differences across all treatments for Stink Lake $(F=$ 3.54, df $=4,10, p=0.048$ ), differences were not large enough for Tukey's post-hoc test to identify homogeneous subsets. There appeared to be a bottle effect for this lake, with a substantial increase in production rates in all treatments compared with the initial values (for example, $669 \mathrm{mg} \mathrm{C} \cdot \mathrm{m}^{-3} \cdot \mathrm{h}^{-1}$ in the control compared with the initial value of $31.5 \mathrm{mg} \mathrm{C} \cdot \mathrm{m}^{-3} \cdot \mathrm{h}^{-1}$ ).

\section{Summer experimental results}

For the summer experiment, three lakes were tested from each of the SUM-N (Alkaline Lake, East Devil's Lake, and Stink Lake) and SUM-P (Clear Lake, Coldwater Lake, and George Lake) groups. Rates of primary production differed among nutrient treatments in five of the six lakes (Fig. 5; Table 4). Of the SUM-N lakes predicted to respond to N, production rates in East Devil's Lake increased in response to the $\mathrm{N}$ addition $(F=25.4, \mathrm{df}=4,10, p<0.001)$. In Alkaline Lake, rates increased in both the $\mathrm{N}$ treatment and the $\mathrm{P}$ treatment $(F=80.9$, df $=4,10, p<0.001)$, with even higher production rates in the $\mathrm{N}+\mathrm{P}$ combination. Interannual differences may have also been important in Alkaline Lake, as this lake was originally classified in the SUM-N group based on 2004 data (Table 5). In the summer of 2006, however, the SRP concentration was undetectable $\left(0.010 \mu \mathrm{g} \cdot \mathrm{L}^{-1}\right.$ detection limit), changing its classification to SUM-P. There were no significant differences in production rates for Stink Lake $(F=1.329$, df $=4,10, p=0.325)$ due to apparent bottle effects for this lake, as in the spring experiments. Control treatment production rates were elevated compared with the initial samples $\left(167 \mathrm{mg} \mathrm{C} \cdot \mathrm{m}^{-3} \cdot \mathrm{h}^{-1}\right.$ in the control versus an initial rate of $\left.23.1 \mathrm{mg} \mathrm{C} \cdot \mathrm{m}^{-3} \cdot \mathrm{h}^{-1}\right)$. In the SUM-P lakes, predicted to be P-limited, Clear Lake had the highest production rates in the $\mathrm{P}$ treatment $(F=26.3$, df $=4,10, p<$ 0.001 ), with no additional response to the $\mathrm{N}+\mathrm{P}$ treatment. Production rates in Coldwater $(F=195.9$, df $=4,10, p<$ $0.001)$ and George $(F=92.0, \mathrm{df}=4,10, p<0.001)$ lakes both increased in the $\mathrm{N}$ addition, along with a significant increase in the $\mathrm{N}+\mathrm{P}$ addition. 
Fig. 3. Lake classification for summer 2004 survey data. C:P ratios, at the top of the figure, were identified as the main splitting variable based on an initial regression tree with primary production as the response metric. On the upper right, high C:P lakes from the CGP region showed a nonsignificant relationship between production and $\mathrm{NO}_{3}{ }^{-}(p=0.073, y=0.281 x+2.636, \mathrm{df}=1,5, F=5.12)$. On the lower left of the figure, lakes from the NGP region were further examined for P limitation with a classification tree with APA: Chl $a$ class (no P limitation or severe limitation) as the response metric. Simple regressions were performed within each subset of lakes. The regressions were statistically significant for the SUM-N $(p=0.043, y=0.0246 x+1.219, \mathrm{df}=1,9, F=5.55)$ and SUM-P $(p=0.009, y=1.063 x-0.194, \mathrm{df}=$ $1,5, F=17.5$ ) groups. Abbreviations: CGP, central Great Plains; NGP, northern Great Plains; SUM-N, potentially N-limited lakes; SUM-P, potentially P-limited lakes.

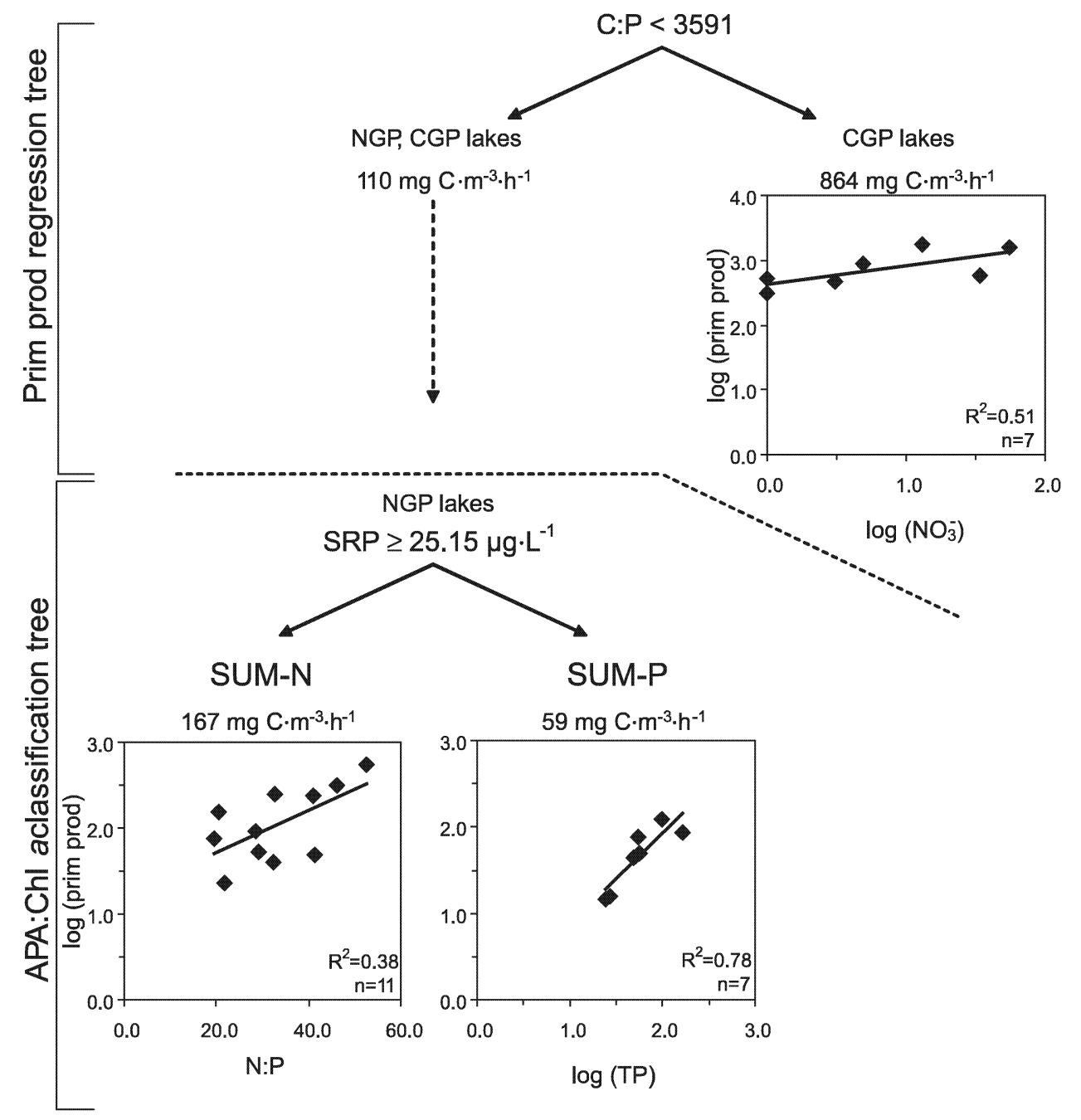

\section{Discussion}

Although previous studies of algal production in saline lakes have been able to identify limitation patterns within a few systems (Bierhuizen and Prepas 1985; Campbell and Prepas 1986; Waiser and Robarts 1995), our study investigated drivers of primary production by phytoplankton across a diverse set of saline lakes. The combination of predictive modeling and experimental tests allowed us to begin to delineate subsets of lakes and determine limitation patterns within them. The models and experiments presented here indicate that despite the high total nitrogen and phosphorus concentrations in these lakes, phytoplankton in these lakes are potentially nutrient-limited. Though many freshwater lakes are often phosphorus-limited (Dillon and Rigler 1974; Wetzel 2001), our results reveal widespread nitrogen limita- tion across these prairie saline lakes. A subset of these lakes is also secondarily limited by $\mathrm{P}$, as indicated by high APA:Chl $a$ ratios and large additional increases in algal production in the experimental $\mathrm{N}+\mathrm{P}$ treatments. Although there is evidence for nitrogen limitation in single saline systems (Reuter et al. 1993), our study provides information on nutrient limitation patterns across a large region in central North America with a high density of subsaline and saline lakes. These data support observations that nitrogen may play a larger and more widespread role in nutrient limitation patterns in lake ecosystems than previously thought (Smith 1982; Elser et al. 1990; Lewis and Wurtsbaugh 2008).

Multiple statistical techniques enabled us to begin to discern these productivity patterns in prairie saline lakes, and results from these various methods were generally in agree- 
Fig. 4. The results from a nutrient enrichment bioassay for spring rates of primary production that experimentally tested the lake classification groups: (a) SPR-NP and (b) SPR-N. Abbreviations: Alk, Alkaline Lake; CW, Coldwater Lake; FP, Free People Lake; ED, East Devil's Lake; Stk, Stink Lake; Prim prod, rate of primary production.

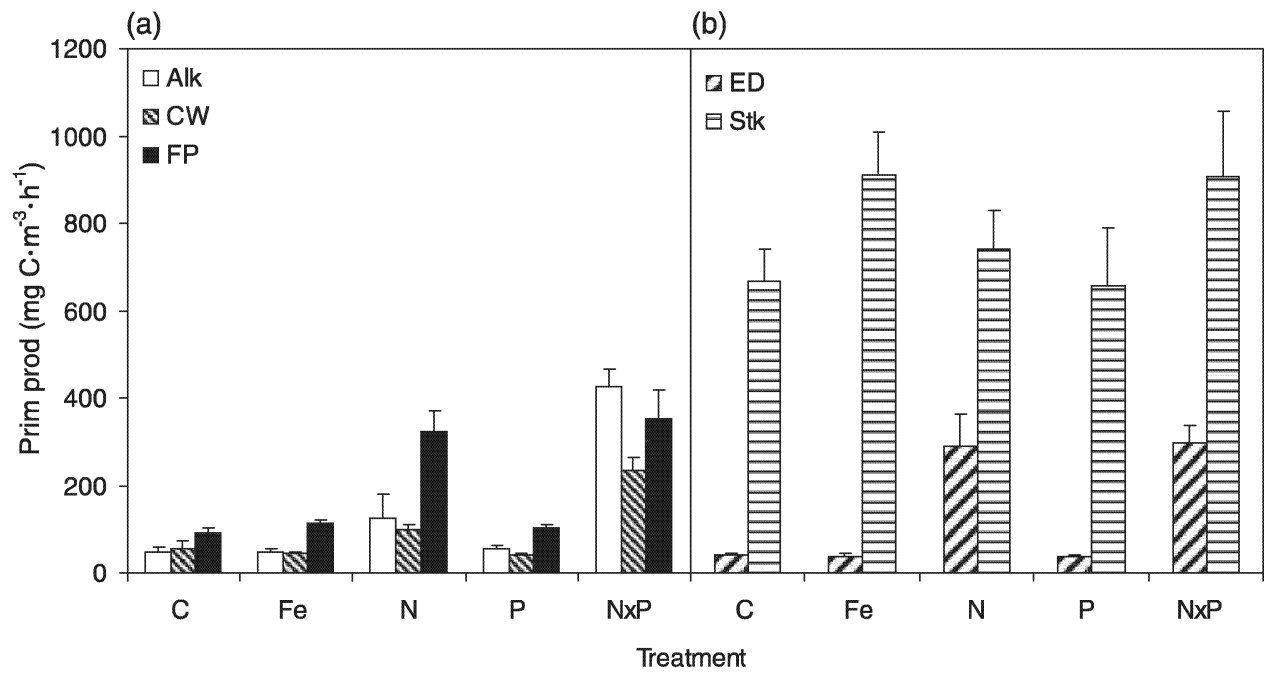

Table 4. Summary of Tukey's post-hoc analyses for spring and summer 2006 experiments.

\begin{tabular}{|c|c|c|c|c|c|c|c|c|c|c|c|}
\hline \multirow[b]{2}{*}{ Treatment } & \multicolumn{5}{|c|}{ Spring } & \multicolumn{6}{|c|}{ Summer } \\
\hline & Alk* & $\mathrm{CW}^{*}$ & $\mathrm{FP}^{*}$ & ED* & $\mathrm{Stk}^{\dagger}$ & Alk* & $\mathrm{ED} *$ & Stk & Clear* & $\mathrm{CW}^{*}$ & Grg* \\
\hline $\mathrm{C}$ & 1 & 1 & 1 & 1 & - & 1 & 1 & - & 1 & 1 & 1 \\
\hline $\mathrm{P}$ & 1,2 & 1 & 1 & 1 & - & 2 & 1 & - & 2 & 1 & 1 \\
\hline $\mathrm{N}$ & 2 & 2 & 2 & 2 & - & 2 & 2 & - & 1 & 2 & 2 \\
\hline $\mathrm{N}+\mathrm{P}$ & 3 & 3 & 2 & 2 & - & 3 & 2 & - & 2 & 3 & 3 \\
\hline
\end{tabular}

Note: Numbers in columns indicate treatments within each lake with responses that are significantly different from each other $(\alpha=0.05)$. Nutrient treatments: C, control; Fe, Fe addition; P, P addition; N, N addition; N + P, combined N and P additions. Lake abbreviations: Alk, Alkaline Lake; CW, Coldwater Lake; FP, Free Peoples Lake; ED, East Devil's Lake; Stk, Stink Lake; Clear, Clear Lake; Grg, George Lake.

$* p<0.001$ for analysis of variance.

$p=0.044$ for analysis of variance, but post-hoc analysis did not detect different subsets of lakes.

$p=0.325$ for analysis of variance. Post-hoc analysis was not performed on these data.

Table 5. Summary of changes in classification groups from 2004 to 2006.

\begin{tabular}{lll}
\hline & \multicolumn{2}{l}{ Survey class } \\
\cline { 2 - 3 } Lake & 2004 & 2006 \\
\hline Spring & & \\
East Devil's & SPR-N & SPR-N \\
Stink & SPR-N & SPR-N \\
Free Peoples & SPR-NP & SPR-N \\
Alkaline & SPR-NP & SPR-NP \\
Coldwater & SPR-NP & SPR-NP \\
Summer & & \\
East Devil's & SUM-N & SUM-N \\
Stink & SUM-N & SUM-N \\
Alkaline & SUM-N & SUM-P \\
Coldwater & SUM-P & SUM-P \\
George & SUM-P & SUM-P \\
Clear & SUM-P & SUM-P \\
\hline
\end{tabular}

Note: Lakes given in italic type indicate changed from predicted 2004 classification based on 2006 data. ment. Simple and multiple regressions identified some potential limiting factors (such as $\mathrm{NO}_{3}{ }^{-}$in the spring for all lakes), but did not suggest singular seasonal controls across the entire suite of lakes. In addition, with covariation among some key parameters in these systems (e.g., correlations between $\log$ TN and $\log$ TP were $R^{2}=0.88$ in spring and $R^{2}=$ 0.64 in summer), it was not possible to identify whether one or both nutrients were actually limiting. Therefore, using additional statistical techniques, we developed more complex models to decipher drivers of productivity patterns across these diverse systems. AIC revealed a complex multivariate story of predictors of primary production, identifying several different predictive models and varying parameter weights. The CART analyses identified a similar group of variables to those from regressions and AIC but produced a simplified hierarchical ordering of these variables and thus served as a useful exploratory tool for examining broad trends across an ecologically complicated data set, as suggested by De'ath and Fabricius (2000). We recognize that the sample size for this study was relatively small, particularly after separating the lakes into subsets, and that more lakes would strengthen these models. However, even with a small sample size, the 
Fig. 5. The results from a nutrient enrichment bioassay for summer rates of primary production that experimentally tested the lake classification groups: (a) SUM-N and (b) SUM-P. Abbreviations: Alk, Alkaline Lake; ED, East Devil's Lake; Stk, Stink Lake; Clear, Clear Lake; $\mathrm{CW}$, Coldwater Lake; Grg, George Lake; Prim prod, rate of primary production.

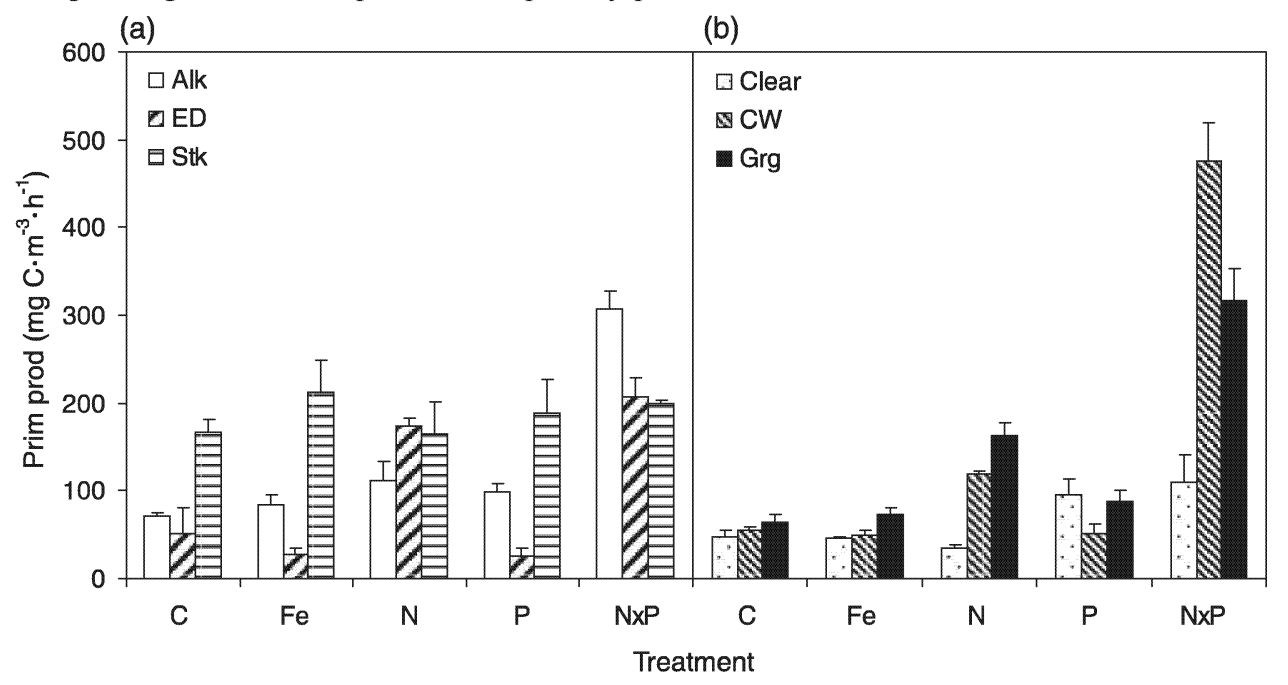

CART models helped to clarify trends within lake groups. Classifications developed from key variables identified with these techniques were easily tested via experiments in 2006. In the spring, the CART models correctly predicted $\mathrm{N}$ limitation in the SPR-N and SPR-NP lakes and secondary P limitation in the SPR-NP lakes. In the summer, lakes in the SUM-N group responded to $\mathrm{N}$ as predicted, except for one lake that changed classification groups in 2006 and was colimited by $\mathrm{N}$ and $\mathrm{P}$. We predicted an increase in production in $\mathrm{P}$ treatments in the SUM-P lakes, and although there was a response to $\mathrm{P}$, two of the three lakes were mainly limited by $\mathrm{N}$ and secondarily by $\mathrm{P}$. Despite this misidentification and generally small sample size, the CART models as a whole enabled us to identify limitation patterns across prairie saline lakes more clearly than in prior studies.

Although ambient nutrient concentrations were high, experimental nutrient additions stimulated primary production by phytoplankton. One explanation for this is the reduced bioavailability of nutrients in these lakes due to complexation with DOM (Hessen and Tranvik 1998; Findlay and Sinsabaugh 2003). As direct measurements of nutrient concentrations did not predict rates of primary production, physiological indicators of nutrient limitation were very important to the success of the lake classification system, with APA : Chl $a$ serving as a reliable tool in discerning patterns of phosphorus limitation among the lakes. Unfortunately, a similarly reliable indicator of nitrogen limitation in these lakes is not apparent. Although $\mathrm{N}_{2}$-fixation rates and heterocyst formation can indicate nitrogen limitation for cyanobacteria, few heterocysts were found in phytoplankton samples from the 2004 sampling (personal observation). C:N ratios of particulate material can be indicative of nitrogen limitation in other aquatic systems, with low $\mathrm{C}: \mathrm{N}$ ratios suggesting that algae are nitrogen replete (Wetzel 2001); however, $\mathrm{C}: \mathrm{N}$ ratios never emerged as significant in our analyses. Furthermore, in many lakes that responded positively to $\mathrm{N}$ additions, initial seston $\mathrm{C}: \mathrm{N}$ values were low (many $<9$ ), which clearly did not reflect the physiological status of the algae.
This observation, in conjunction with the extremely high seston $\mathrm{C}: \mathrm{P}$ ratios in these lakes, raises the question of what these $\mathrm{C}$ ratios really reflect in these high DOM lakes. The development of additional physiological metrics would greatly improve our ability to assess $\mathrm{N}$ limitation patterns in these prairie lakes.

Our results indicate broad nitrogen limitation in lakes across this semi-arid region; other studies have also found $\mathrm{N}$ limitation in single saline lakes (Cloern et al. 1983; Herbst and Bradley 1989; Reuter et al. 1993). Terrestrial sources of nitrogen may be less abundant in grasslands than in forested areas, as humid grasslands tend to be nitrogenlimited with low soil $\mathrm{N}$ availability (Wedin 1995). These systems may be further driven to $\mathrm{N}$ limitation by various feedbacks, as dry conditions in grasslands slow $\mathrm{N}$ mineralization rates of already low quality (high $\mathrm{C}: \mathrm{N}$ ) litter (Wedin 1995). Other important feedbacks to consider in these prairie ecosystems include grazing and fire effects, as grazing tends to recycle $\mathrm{N}$ (Holland et al.1992) and fire tends to volatilize $\mathrm{N}$ (Ojima et al. 1994). In contrast to wetter temperate regions, reduced precipitation in grasslands can also decrease nutrient inputs from terrestrial runoff.

Nitrogen limitation in prairie saline lakes may also be caused by different physical and chemical conditions in these systems, which lead to $\mathrm{N}$ loss from the system and $\mathrm{P}$ release from sediments. Physically, lakes in the CGP and NGP tend to be shallow and turbulent, and the resulting variable mixing patterns could lead to alternating aerobic and anaerobic conditions at the lake bottom. These varying conditions allow for high rates of denitrification, a common pathway for nitrogen loss in shallow systems (Jensen and Andersen 1990). Though aerobic conditions typically cause $\mathrm{P}$ to precipitate out of the water column due to binding with $\mathrm{Fe}$, turbulence also resuspends sediment and may cause overall $\mathrm{P}$ release if conditions vary between aerobic and anaerobic (Søndergaard et al. 1992). Chemically, Fe-P binding is reduced at high $\mathrm{pH}$ (Lijklema 1977), and all study lakes had $\mathrm{pH}$ greater than 8.3. There is also evidence for al- 
tered $\mathrm{P}$ cycling under high sulfate concentrations, as the sulfate tends to bind $\mathrm{Fe}$ and thereby reduce $\mathrm{Fe}-\mathrm{P}$ binding (Caraco et al. 1989; Curtis 1989). Saline lakes, particularly those in the NGP, can have high sulfate concentrations, and although ion concentrations did not directly correlate with primary production rates, sulfate may indirectly influence nutrient availability in these systems.

Although Fe was a top predictor variable for primary production in AIC and multiple regression models, the CART analyses did not identify Fe as important, and there was little evidence for Fe limitation in experimental results. In the spring experiments, a Chroococcus sp. in Stink Lake did increase substantially in biovolume in the Fe treatment (personal observation), suggesting that $\mathrm{Fe}$ was biologically available for uptake in this lake and season. Our results show that limitation by two or possibly more nutrients could be very important in controlling production in prairie lakes, and previous studies have indicated the potential of $\mathrm{Fe}$ and other trace metals (Marino et al. 1990; Evans and Prepas 1997) to act as limiting factors in prairie saline lakes. Future studies should consider the effects of not only single nutrient additions, but also those of combination treatments as well.

Lakes in the CGP were generally more productive than those of the NGP and, in the spring, had higher nitrate concentrations. Precipitation gradients are similar in both regions, but the higher $\mathrm{N}$ and hence productivity of the CGP lakes may be due to the higher temperatures in this region, which could increase terrestrial $\mathrm{N}$ mineralization rates, as well as $\mathrm{N}_{2}$ fixation rates by cyanobacteria (Macarelli and Wurtsbaugh 2006; Scott et al. 2008). Land-use patterns also differ across these two regions, with the CGP serving as cattle rangeland and the NGP largely serving as arable agricultural land, some of which has been abandoned during recent decades. These differences in land use, as well as local geology as described above, may contribute to the higher productivity levels in the CGP lakes.

Shallow lakes and wetlands in prairie regions provide important ecosystem services, including carbon sequestration, wildlife habitat, and recreation (Batt et al. 1989; Euliss et al. 2006). These ecosystem services all involve algal production and standing crops, and hence a greater understanding of the factors that control primary production across these lakes is a critical aspect for ensuring the sustainability of these services. Our analyses suggest that patterns of primary production in prairie saline lakes of the central and northern Great Plains were complex. Although no trends were consistent across all saline lakes, likely due to geochemical and physical differences among these varied systems, exploratory classification models generally were successful in identifying productivity patterns within lake subsets. Nitrogen limitation was widespread in these systems, especially in spring, along with secondary limitation by phosphorus in some cases. The CART exploratory classification technique shows promise for determining primary production patterns across a complicated data set, and the resultant classification could be refined with a larger data set as well as with better physiological tools to assess limitation by nitrogen and possibly other nutrients. Prairie saline lakes are globally important systems, and thus, understanding the ecology of these complex systems is an essential component of a more com- prehensive understanding of lake ecosystem function and structure.

\section{Acknowledgements}

We thank Danuta Bennett, Jessica Czubakowski, Carmen Daggett, Jarvis Erickson, Margaret Henke, Callie Martin, Brian McMullen, Caren Scott, Robert Toban, and Erin Wilcox for field and laboratory assistance. The Water Sciences Laboratory at the University of Nebraska - Lincoln conducted the iron, anion, and total nutrient analyses; we thank the director, Daniel D. Snow, for assistance with selection of appropriate analytical techniques. John Holz and Tad Barrow provided advice on lake selection in the CGP, as well as nutrient analyses and field assistance, and Leigh Stearns provided the map of study locations. We thank three anonymous reviewers for their helpful comments, which greatly improved this manuscript. This work was funded by the National Science Foundation (DEB-0315665). Additional funding was provided by a University of Wisconsin - La Crosse Graduate Research Grant and the River Studies Center (University of Wisconsin - La Crosse).

\section{References}

American Public Health Association. 1998. Standard methods for the examination of water and wastewater. 20th ed. APHA, Washington, D.C.

Anderson, G.C. 1958. Seasonal characteristics of two saline lakes in Washington. Limnol. Oceanogr. 3: 51-68.

Armstrong, R., Anderson, D., and Callender, E. 1966. Primary productivity measurements at Devil's Lake, North Dakota. North Dakota Academy of Science, 20: 136-149.

Arts, M.T., Robarts, R.D., Kasai, F., Waiser, M.J., Tumber, V.P., Plante, A.J., Rai, H., and de Lange, H.J. 2000. The attenuation of ultraviolet radiation in high dissolved organic carbon waters of wetlands and lakes on the northern Great Plains. Limnol. Oceanogr. 45: 292-299.

Batt, B.D., Anderson, M.G., Anderson, C.D., and Caswell, F.D. 1989. The use of prairie potholes by North American ducks. In Northern prairie wetlands. Edited by A.G. van der Valk. Iowa State Press, Ames, Iowa. pp. 204-227.

Bierhuizen, J.F.H., and Prepas, E.E. 1985. Relationship between nutrients, dominant ions, and phytoplankton standing crop in prairie saline lakes. Can. J. Fish. Aquat. Sci. 42: 1588-1594. doi:10.1139/f85-199.

Bluemle, J.P., and Clayton, L. 1984. Large-scale glacial thrusting and related processes in North Dakota. Boreas, 13: 279-299.

Bulley, H.N.N., Merchant, J.W., Marx, D.B., Holz, J.C., and Holz, A.A. 2007. A GIS approach to watershed classification for Nebraska reservoirs. J. Am. Water Resour. Assoc. 43(3): 605-621. doi:10.1111/j.1752-1688.2007.00048.x.

Burnham, K.P., and Anderson, D.R. 2002. Model selection and multimodel inference: a practical information-theoretic approach. Springer, New York.

Bushaw-Newton, K.L., and Moran, M.A. 1999. Photochemical formation of biologically available nitrogen from dissolved humic substances in coastal marine systems. Aquat. Microb. Ecol. 18: 285-292. doi:10.3354/ame018285.

Campbell, C.E., and Prepas, E.E. 1986. Evaluation of factors related to the unusually low chlorophyll levels in prairie saline lakes. Can. J. Fish. Aquat. Sci. 43: 846-854. doi:10.1139/f86104.

Caraco, N.F., Cole, J.J., and Likens, G.E. 1989. Evidence for 
sulphate-controlled phosphorus release from sediments of aquatic systems. Nature (London), 341(6240): 316-318. doi:10.1038/341316a0.

Cloern, J.E., Cole, B.E., and Oremland, R.S. 1983. Seasonal changes in the chemistry and biology of a meromictic lake (Big Soda Lake, Nevada, U.S.A.). Hydrobiologia, 105(1): 195-206. doi:10.1007/BF00025188.

Cole, J.J., Howarth, R.W., Nolan, S.S., and Marino, R. 1986. Sulfate inhibition of molybdate assimilation by planktonic algae and bacteria: some implications for the aquatic nitrogen cycle. Biogeochemistry, 2(2): 179-196. doi:10.1007/BF02180194.

Cumming, B.F., and Smol, J.P. 1993. Development of diatombased salinity models for paleoclimatic research from lakes in British Columbia (Canada). Hydrobiologia, 269/270(1): 179196. doi:10.1007/BF00028017.

Curtis, P.J. 1989. Effects of hydrogen ion and sulphate on the phosphorus cycle of a Precambrian Shield Lake. Nature (London), 337(6203): 156-158. doi:10.1038/337156a0.

Curtis, P.J., and Adams, H.E. 1995. Dissolved organic matter quantity and quality from freshwater and saltwater lakes in east-central Alberta. Biogeochemistry, 30(1): 59-76. doi:10.1007/ BF02181040.

D'Elia, C.F., Studler, P.A., and Corwin, N. 1977. Determination of total nitrogen in aqueous samples using persulfate digestion. Limnol. Oceanogr. 22: 760-764.

De Haan, H., and De Boer, T. 1987. Applicability of light absorbance and fluorescence as measures of concentration and molecular size of dissolved organic carbon in humic Lake Tjeukemeer. Water Res. 21(6): 731-734. doi:10.1016/00431354(87)90086-8.

De'ath, G., and Fabricius, K.E. 2000. Classification and regression trees: a powerful yet simple technique for ecological data analysis. Ecology, 81: 3178-3192.

Dillon, P.J., and Rigler, F.H. 1974. The phosphorus-chlorophyll relationship in lakes. Limnol. Oceanogr. 19: 767-773.

Donovan, J.J. 1994. On the measurement of reactive mass fluxes in evaporative groundwater-source lakes. In Sedimentology and geochemistry of modern and ancient saline lakes. Edited by R.W. Renaut and W.M. Last. Society for Sedimentary Geology, Tulsa, Oklahoma. pp. 33-50.

Downes, M.T. 1978. An improved hydrazine reduction method for the automated determination of low nitrate levels in freshwater. Water Resour. 12(9): 673-675. doi:10.1016/0043-1354(78) 90177-X.

Elser, J.J., Marzolf, E.R., and Goldman, C.R. 1990. Phosphorus and nitrogen limitation of phytoplankton growth in freshwaters of North America: a review and critique of experimental enrichments. Can. J. Fish. Aquat. Sci. 47: 1468-1477. doi:10.1139/ f90-165.

Elser, J.J., Fagan, W.F., Denno, R.F., Dobberfuhl, D.R., Folarin, A., Huberty, A., Interlandi, S., Kilham, S.S., McCauley, E., Schulz, K.L., Siemann, E.H., and Sterner, R.W. 2000. Nutritional constraints in terrestrial and freshwater food webs. Nature (London), 408(6812): 578-580. doi:10.1038/35046058. PMID: 11117743.

Emmons, E.E., Jennings, M.J., and Edwards, C. 1999. An alternative classification method for northern Wisconsin lakes. Can. J. Fish. Aquat. Sci. 56(4): 661-669. doi:10.1139/cjfas-56-4-661.

Euliss, N.H., Jr., Gleason, R.A., Olness, A., McDougal, R.L., Murkin, H.R., Robarts, R.D., Bourbonierre, R.A., and Warner, B.G. 2006. North American prairie wetlands are important nonforested carbon storage sites. Sci. Total Environ. 369: 179-188.

Evans, J.C., and Prepas, E.E. 1997. Relative importance of iron and molybdenum in restricting phytoplankton biomass in high phosphorus saline lakes. Limnol. Oceanogr. 42: 461-472.

Findlay, S.E.G., and Sinsabaugh, R.L. (Editors). 2003. Aquatic ecosystems: interactivity of dissolved organic matter. Academic Press, San Diego, Calif.

Fritz, S.C., Juggins, S., and Battarbee, R.W. 1993. Diatom assemblages and ionic characterization of lakes of the northern Great Plains, North America: a tool for reconstructing past salinity and climate fluctuations. Can. J. Fish. Aquat. Sci. 50(9): 1844-1856. doi:10.1139/f93-207.

Fritz, S.C., Ito, E., Yu, Z., Laird, K.R., and Engstrom, D.R. 2000. Hydrologic variation in the northern Great Plains during the last two millenia. Quat. Res. 53(2): 175-184. doi:10.1006/qres.1999. 2115 .

Gosselin, D.C. 1997. Major-ion chemistry of compositionally diverse lakes, western Nebraska, U.S.A.: implications for paleoclimatic interpretations. J. Paleolimnol. 17(1): 33-49. doi:10.1023/ A:1007908909148.

Hammer, U.T. 1981. Primary production in saline lakes. Hydrobiologia, 81(1): 47-57. doi:10.1007/BF00048705.

Healey, F.P., and Hendzel, L.L. 1980. Physiological indicators of nutrient deficiency in lake phytoplankton. Can. J. Fish. Aquat. Sci. 37(3): 442-453. doi:10.1139/f80-058.

Herbst, D.B., and Bradley, T.J. 1989. Salinity and nutrient limitations on growth of benthic algae from two alkaline salt lakes of the western Great Basin (USA). J. Phycol. 25(4): 673-678. doi:10.1111/j.0022-3646.1989.00673.x.

Hessen, D.O., and Tranvik, L.J. (Editors). 1998. Aquatic humic substances. Springer, Berlin, Germany.

Hill, H.D., Summer, G.K., and Waters, M.D. 1968. An automated fluorometric assay for alkaline phosphatase using 3- $O$-methylfluorescein phosphate. Anal. Biochem. 24(1): 9-17. doi:10. 1016/0003-2697(68)90054-7. PMID:5665203.

Holland, E.A., Parton, W.J., Detling, J.K., and Coppock, D.L. 1992. Physiological responses of plant populations to herbivory and their consequences for ecosystem nutrient flow. Am. Nat. 140(4): 685-706. doi:10.1086/285435. PMID:19426039.

Jensen, H.S., and Andersen, F.Ø. 1990. Impact of nitrate and bluegreen algae abundance on phosphorus cycling between sediment and water in two shallow eutrophic lakes. Verh. Int. Verein. Limnol. 24: 224-230.

Kirk, J.T.O. 1994. Light and photosynthesis in aquatic ecosystems. 2nd ed. Cambridge University Press, Cambridge, UK.

LaBaugh, J.W. 1986. Limnological characteristics of selected lakes in the Nebraska Sandhills, U.S.A., and their relation to chemical characteristics of adjacent ground water. J. Hydrol. (Amst.), 86(3-4): 279-298. doi:10.1016/0022-1694(86)90168-X.

Laird, K.R., Fritz, S.C., and Cumming, B.F. 1998. A diatom-based reconstruction of drought intensity, duration, and frequency from Moon Lake, North Dakota: a sub-decadal record of the last 2300 years. J. Paleolimnol. 19(2): 161-179. doi:10.1023/ A: 1007929006001 .

Lewis, W.M., Jr., and Wurtsbaugh, W.A. 2008. Control of lacustrine phytoplankton by nutrients: erosion of the phosphorus paradigm. Int. Rev. Hydrobiol. 93(4-5): 446-465. doi:10.1002/iroh. 200811065.

Lijklema, L. 1977. The role of iron in the exchange of phosphate between water and sediments. In Interactions between sediments and freshwater. Edited by H.L. Golterman. Dr W. Junk Publishers, New York. pp. 313-317.

Lind, O.T. 1985. Handbook of common methods in limnology. Kendall/Hall Publishing Company, Dubuque, Iowa.

Loope, D.B., Swinehart, J.B., and Mason, J.P. 1995. Dune-dammed paleovalleys of the Nebraska Sand Hills: intrinsic versus cli- 
matic controls on the accumulation of lake and marsh sediments. Geol. Soc. Am. Bull. 107(4): 396-406. doi:10.1130/00167606(1995)107<0396:DDPOTN>2.3.CO;2.

Macarelli, A.M., and Wurtsbaugh, W.A. 2006. Temperature and nutrient supply interact to control nitrogen fixation in oligotrophic streams: an experimental examination. Limnol. Oceanogr. 51: 2278-2289.

Marino, R., Howarth, R.W., Shamess, J., and Prepas, E.E. 1990. Molybdenum and sulfate as controls on the abundance of nitrogen-fixing cyanobacteria in saline lakes in Alberta. Limnol. Oceanogr. 35: 245-259.

Mason, J.P., Swinehart, J.B., and Loope, D.B. 1997. Holocene history of lacustrine and marsh sediments in a dune-blocked drainage, southwestern Nebraska Sand Hills, USA. J. Paleolimnol. 17(1): 67-83. doi:10.1023/A:1007917110965.

Ojima, D.S., Schimel, D.S., Parton, W.J., and Owensby, C.E. 1994. Long- and short-term effects of fire on nitrogen cycling in tallgrass prairie. Biogeochemistry, 24(2): 67-84. doi:10.1007/ BF02390180.

Osburn, C.L., and St. Jean, G. 2007. The use of wet chemical oxidation with high-amplification isotope ratio mass spectrometry (WCO-IRMS) to measure stable isotope values of dissolved organic carbon in seawater. Limnol. Oceanogr. Methods, 5: 296308.

Reuter, J.E., Rhodes, C.L., Lebo, M.E., Kotzman, M., and Goldman, C.R. 1993. The importance of nitrogen in Pyramid Lake (Nevada, USA), a saline, desert lake. Hydrobiologia, 267(1-3): 179-189. doi:10.1007/BF00018800.

Robarts, R.D., Evans, M.S., and Arts, M.T. 1992. Light, nutrients and water temperatures as determinants of phytoplankton production in two saline prairie lakes with high sulfate concentrations. Can. J. Fish. Aquat. Sci. 49: 2281-2290. doi:10.1139/ f92-250.

Salm, C.R., Saros, J.E., Martin, C.S., and Erickson, J.M. 2009. Patterns of seasonal phytoplankton distribution in prairie saline lakes of the northern Great Plains (U.S.A.). Saline Systems, 5(1). doi:10.1186/1746-1448-5-1. PMID:19123939.
Saros, J.E., and Fritz, S.C. 2000. Nutrients as a link between ionic concentration/composition and diatom distributions in saline lakes. J. Paleolimnol. 23(4): 449-453. doi:10.1023/ A:1008186431492

Scott, J.T., Doyle, R.D., Prochnow, S.J., and White, J.D. 2008. Are watershed and lacustrine controls on planktonic $\mathrm{N}_{2}$ fixation hierarchically structured? Ecol. Appl. 18(3): 805-819. doi:10.1890/ 07-0105.1. PMID:18488636.

Smith, V.H. 1979. Nutrient dependence of primary productivity in lakes. Limnol. Oceanogr. 24: 1051-1064.

Smith, V.H. 1982. The nitrogen and phosphorus dependence of algal biomass in lakes: an empirical and theoretical analysis. Limnol. Oceanogr. 27: 1101-1112.

Søndergaard, M., Kristensen, P., and Jeppesen, E. 1992. Phosphorus release from resuspended sediment in the shallow and wind-exposed Lake Arres $\varnothing$, Denmark. Hydrobiologia, 228: $91-$ 99. doi:10.1007/BF00006480.

Søndergaard, M., Jeppesen, E., Jensen, J.P., and Amsinck, S.L. 2005. Water Framework Directive: ecological classification of Danish lakes. J. Appl. Ecol. 42(4): 616-629. doi:10.1111/j. 1365-2664.2005.01040.x.

Sterner, R.W., and Elser, J.J. 2002. Ecological stoichiometry: the biology of elements from molecules to the biosphere. Princeton University Press, Princeton, N.J.

Waiser, M.J., and Robarts, R.D. 1995. Microbial nutrient limitation in prairie saline lakes with high sulfate concentration. Limnol. Oceanogr. 40: 566-574

Wedin, D.A. 1995. Species, nitrogen, and grassland dynamics: the constraints of stuff. In Linking species and ecosystems. Edited by C.G. Jones and J.H. Lawton. Chapman \& Hall, New York. pp. 253-262.

Wetzel, R.G. 2001. Limnology: lake and river ecosystems. 3rd ed. Academic Press, San Diego, Calif.

Wetzel, R.G., and Likens, G.E. 1991. Limnological analyses. 2nd ed. Springer-Verlag, New York.

Williams, W.D. 1981. Inland salt lakes: an introduction. Hydrobiologia, 81-82(1): 1-14. doi:10.1007/BF00048701. 